\title{
Upaya Kepolisian Dalam Penanggulangan Tindak Pidana Kekerasan yang Dilakukan Pelajar (Studi Wilayah Hukum Polres Dompu)
}

\author{
Neneng Anggraini' ${ }^{1}$, Zaini Bidaya ${ }^{2}$, Zedi Muttaqin ${ }^{3}$ \\ ${ }^{1}$ Pendidikan Pancasila dan Kewarganegaraan, Universitas Muhammadiyah Mataram, Email: neneng.anggraini18@gmail.com \\ ${ }^{2}$ Pendidikan Pancasila dan Kewarganegaraan, Universitas Muhammadiyah Mataram, Email: zainibidaya14@gmail.com \\ ${ }^{3}$ Pendidikan Pancasila dan Kewarganegaraan, Universitas Muhammadiyah Mataram, Email: zedi.muttaqin45@gmail.com
}

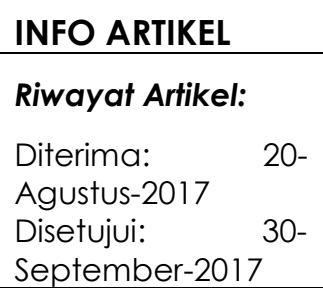

Kata Kunci:

polisi penanggulangan tindak pidana kekerasan

\begin{abstract}
ABSTRAK
Abstrak: Peristiwa kenakalan anak-anak yang mengarah kepada tindak pidana kekerasan yang terjadi di Dompu berupa kekerasan fisik seperti memukul, menendang, jambak dan lain-lain. Tujuan penelitian ini untuk mengetahui upaya kepolisian dalam penanggulangan tindak pidana kekerasan yang dilakukan oleh pelajar dan untuk mengetahui kendala yang dihadapi kepolisian dalam menangani masalah tindak pidana kekerasan yang dilakukan oleh pelajar di Dompu. Metode penelitian menggunakan metode hukum empiris, dengan pendekatan sosiologis hukum. Pengumpulan data menggunakan tiga yaitu, observasi, wawancara, dan dokumentasi. Tehnik analisis data melalui tiga tahapan yaitu, reduksi data, penyajian data, dan menarik kesimpulan. Berdasarkan uraian hasil penelitian dan analisis data, dapat disimpulkan bahwa upaya kepolisian dalam penanggulangan tindak pidana kekerasan yang dilakukan oleh pelajar di Dompu, yaitu melalui penyuluhan-penyuluhan disetiap sekolah maupun desa-desa, dan melakukan kerja sama dengan berbagai komponen atau lembaga yang berkaitan. Sedangkan kendala yang dihadapi kepolisian yaitu pelaku bungkam dan menutup diri karena belum siap masuk ranah hukum, status tersangka sebagai seorang pelajar dan jelas masih di bawah umur para penyidik tidak bisa melakukan penyidikan selayaknya orang dewasa. Belum adanya Balai Pemasyarakatan di Dompu sehingga memperlambat proses penyelidikan. Dan orang tua pelaku yang tidak mau mendampingi anaknya saat proses penyelidikan dilakukan karena merasa malu malu, marah, dan kecewa kepada anaknya.
\end{abstract}

\begin{abstract}
The events of the delinquency of children which leads to criminal acts of violence that occurred in Dompu in the form of physical violence such as hitting, kicking, tuft and others. The purpose of this research is to know the efforts of the police force in tackling violent crime done by students and to know the obstacles faced in dealing with the issue of police criminal acts of violence committed by students in Dompu. Research method using the method of empirical laws, with sociological approaches to law. Use the three data collection i.e., observation, interviews, and documentation. Technical data analysis through three stages, namely, the reduction of the data, the presentation of the data, and draw conclusions. Based on the description of the results of research and data analysis, it can be concluded that the efforts of the police force in tackling violent crime committed by students in Dompu, namely through the extension-extension at each school as well as villages, and do work closely with the various components or related institutions. While the obstacles faced and tight-lipped offender i.e. police shut down because not ready to enter the realm of the law, the status of the suspect as a learner and obviously still under the investigator could not do the investigation as they do adults. Yet the existence of prisons in Dompu Hall so as to slow down the process of the investigation. Parents and principals who did not want to accompany his son while the inquiry process is done because of being ashamed, angry, embarrassed and disappointed to his son.
\end{abstract}

\section{A. LATAR BELAKANG}

Undang-undang Hukum Pidana di Indonesia, dalam literatur hukum pidana terdapat beberapa istilah yang yang dikemukkan oleh para ahli. perbuatan pidana adalah sebagai berikut[1] perbuatan pidana adalah perbuatan yang dilarang oleh suatu aturan hukum larangan mana disertai ancaman (sanksi) yang berupa pidana tertentu, bagi barang siapa yang melanggar larangan tersebut. Dapat juga dikatakan bahwa perbuatan pidana adalah perbuatan yang oleh suatu aturan hukum dilarang dan diancam pidana, asal saja dalam pada itu diingat bahwa larangan ditujukan kepada perbuatan (yaitu suatu keadaan atau kejadian yang ditimbulkan oleh kelakuan orang), sedangkan ancaman pidananya ditujukan kepada orang yang menimbulkan kejadian itu.

Kenakalan anak-anak yang dianggap wajar ternyata tidak jarang menyebabkan anak-anak tersebut 
melakukan kejahatan (anak yang berkonflik dengan hukum). Seringkali hak-hak anak yang melakukan kejahatan atau yang berkonflik dengan hukum tersebut tidak dilindungi pada setiap tingkat pemeriksaan mulai dari proses penyidikan hingga proses persidangan di pengadilan. Belum lagi situasi lain yang harus dihadapi. Stigma dari masyarakat sebagai penjahat, harus keluar dari sekolahnya dan diasingkan oleh komunitas lingkungannya. Kondisi ini sangat berpengaruh terhadap perkembangan anak dan masa depannya[2].

Tindak pidana yang dilakukan anak jalanan di antara lain memalak, memeras dan melakukan ancaman kepada korban[3]. Indonesia memiliki aturan untuk melindungi, mensejahterakan dan memenuhi hak-hak anak antara lain Undang-Undang Kesejahteraan Anak No. 4 Tahun 1979, Undang-Undang Pengadilan Anak No. 3 Tahun 1997 dan Undang-Undang Perlindungan Anak No 3 Tahun 2002 namun tidak membawa perubahan signifikan bagi nasib anak-anak yang berkonflik karena tidak menempatkan restorative juastice pada peraturan perundangan yang ada. Pengaturan sanksi tersebut masih berpijak pada filosofi pemidanaan yang bersifat retributif sehingga tidak menjamin perlindungan hakhak anak.Diversi dan konsep restorative justice perlu menjadi bahan pertimbangan dalam penanganan kasus anak. Konsep ini melibatkan semua pihak dalam rangka untuk perbaikan moral anak[4].

Peristiwa kenakalan anak-anak yang mengarah kepada tindak pidana kekerasan yang terjadi di Dompu yang berupa kekerasan fisik seperti memukul, menendang, menjambak dan lain-lain. Selain bullying, kekerasan antar siswa yang sering terjadi adalah tawuran. Selain kekerasan fisik juga terjadi kekerasan verbal seperti mengejek, menghina atau mengucapkan kata-kata yang menyinggung atau membuat cerita bohong yang menyebabkan siswa yang menjadi sasaran menjadi terkucilkan atau menjadi bahanolok-olok sehingga siswa yang bersangkutan menjadi rendah diri, takut dan sebagainya.

Untuk menegakkan aturan, maka lembaga yang berwenang untuk menyelesaikan tindakan pidana anak adalah Kepolisian Republik Indonesia. Penegak hukum yang berwenang dalam hal ini adalah polisi mempunyai peran dan tanggung jawab menurut [5] Pasal 13 mengatakan bahwa tugas pokok Kepolisian Negara Republik Indonesia adalah; 1). Memelihara keamanan dan ketertiban masyarakat. 2). Menegakan hokum. dan 3). Memberikan perlin-dungan, pengayoman, dan pelayanan kepada masyarakat.

Menjalankan tugas dan fungsinya sebagai penegak hukum Kepolisian dapat bertindak secara preventif maupun represif. Dengan adanya tindakan dari kepolisian ini diharapkan dapat memberikan pengarahan kepada remaja maupun anak-anak yang belum melakukan tindak pidana dan memberikan efek jera terhadap anak yang sudah melakukan tindak pidana, walaupun demikian penanganan kasus tindak pidana yang dilakukan oleh anak tidaklah sama seperti penanganan kasus tindak pidana yang dilakukan oleh orang dewasa, pihak penegak hukum harus tetap memperhatikan kondisi fisik maupun mental anak tersebut karena bagaimanapun anak adalah generasi penerus bangsa.

Undang-undang Hukum Pidana di Indonesia, dalam literatur hukum pidana terdapat beberapa istilah yang yang dikemukkan oleh para ahli. perbuatan pidana adalah "Perbuatan pidana adalah perbuatan yang dilarang oleh suatu aturan hukum larangan mana disertai ancaman (sanksi) yang berupa pidana tertentu, bagi barang siapa yang melanggar larangan tersebut. Dapat juga dikatakan bahwa perbuatan pidana adalah perbuatan yang oleh suatu aturan hukum dilarang dan diancam pidana, asal saja dalam pada itu diingat bahwa larangan ditujukan kepada perbuatan (yaitu suatu keadaan atau kejadian yang ditimbulkan oleh kelakuan orang), sedangkan ancaman pidananya ditujukan kepada orang yang menimbulkan kejadian itu[6]."

Istilah tindak pidana atau dalam bahasa belanda, strafbaar feit, yang sebenarnya merupakan istilah resmi dalam strafwetboek atau kitab Undang-Undang Hukum pidana, yang sekarang berlaku di Indonesia. Ada istilah dalam bahasa asing, yaitu delict.

Secara harfiah tindak pidana (strafbaarfeit), berasal dari dua kata yaitu stafbaaryang berarti hukum, dan feityang berarti sebagian suatu kenyataan yang dapat dihukum [7]. Sedangkan menurut pembentukan perundang-undang kata perkataan strafbaarfeit untuk menyebutkan tindak pidana sebagaimana yang kita kenal dan yang ada dalam KUHP tanpa memberikan suatu penjelasan mengenai apa sebenarnya. Jadi umumnya tindak pidana merupakan suatu perbuatan yang melanggar hukum, dan bertentangan dengan peraturan perundang-undangan yang berlaku.

Menurut hemat peneliti terjemahannya (strafbaarfeit) ke dalam beberapa istilah, bukan merupakan suatu masalah, asal saja dengan menggunakan istilah yang bermacam-macam untuk suatu maksud yang diberikan suatu keterangan yang cukup jelas dengan maksud untuk menghindari adanya kesalahan didalam penafsiran.Terdapat beberapa istilah sebagai terjemahan (strafbaarfeit) tersebut karena sesungguhnya di dalam literatur belanda tentang arti (strafbaarfeit) pada saat ini sedang mengalami perkembangan penulis menggunakan istilah tindak pidana dengan tidak mengurangi penghargaan terhadap para serjana yang telah terjemahkan istilah (strafbaarfeit) dengan bermacam-macam istilah [7].

Kejahatan adalah suatu nama atau cap yang diberikan orang untuk menilai perbuatan-perbuatan tertentu, sebagai perbuatan jahat. Dengan demikian maka pelaku disebut sebagai penjahat. Pengertian tersebut bersumber dari alam nilai,maka ia memiliki pengertian yang sangat relatife, yaitu tergantung pada manusia yang memberikan penilain itu. Jadi apa yang 
disebut kejahatan oleh seseorang belum tentu diakui oleh pihak lain sebagai suatu kejahatan pula. Kalaupun misalnya semua golongan dapat menerima sesuatu itu merupakan kejahatan tapi berat ringannya perbuatan masih menimbulkan perbedaan pendapat diantara para sarjana. Kebijakan penanggulan kejahatan atau tang biasa disebut dengan istilah politik kriminal dapat meliputi lingkup yang cukup luas. Dalam sejarah kelahiran masyarakat dan Negara, tugas-tugas menciptakan dan menjaga situasi aman dan tentram dalam masyarakat dipercayakan kepada petugas keamanan yaitu polisi. Dengan demikian polisi menjadi ujung tombak Negara bagi keberhasilan sebagai pelindung, pengayom, dan pelayan masyarakat.

Sesuai dengan kamus umum bahasa Indonesia bahwa, polisi diartikan sebagai badan pemerintah yang bertugas memelihara keamanan dan ketertiban umum seperti menangkap orang yang melanggar undangundang dan sebagainya anggota dari pemerintahan diatas adalah pegawai negeri menjaga keamanan dan sebagainya. Dengan demikian arti polisi tetap ditonjolkan sebagai badan atau lembaga yang seyoginya menjalankan fungsi pemerintahan dan sebagai sebutan anggota dari lembaga [8].

Kepolisian sesuai yang tercantum dalam pasal 1 ayat 1 [9], menyatakan bahwa Kepolisian adalah hal ihwal yang berkaitan dengan fungsi dan lembaga polisi sesuai dengan peraturan perundang-undangan. Sementara itu Anggota Kepolisian Negara Republik Indonesia adalah pegawai negeri pada Kepolisian Negara Republik Indonesia [9].

Tindak pidana kekerasan yang dilakukan kalangan pelajar makin marak terjadi, bahkan antar sekolah. Hal ini terjadi di wilayah hukum Polres Dompu, sehingga urgen untuk ditanggulangi mengingat secara tepat dan mendidik. Peristiwa kenakalan anak-anak yang mengarah kepada tindak pidana kekerasan yang terjadi di Dompu berupa kekerasan fisik seperti memukul, menendang, jambak dan lain-lain. Penegak hukum yang berwenang dalam hal ini adalah polisi mempunyai peran dan tanggung jawab menurut Pasal 13 [9] mengatakan bahwa tugas pokok Kepolisian Negara Republik Indonesia adalah Memelihara keamanan dan ketertiban masyarakat. Penegakan hukum dan memberikan perlindungan, pengayoman, dan pelayanan kepada masyarakat. Tujuan penelitian ini yaitu untuk mengetahui upaya kepolisian dalam penanggulangan tindak pidana kekerasan yang dilakukan oleh pelajar dan untuk mengetahui kendala yang dihadapi kepolisian dalam menangani masalah tindak pidana kekerasan yang dilakukan oleh pelajar di Dompu.

\section{B. METODE PENELITIAN}

\section{Metode Penelitian yang Digunakan}

Metode penelitian hukum sosiologis (empiris), hukum dikonsepkan sebagai pranata sosial yang secara riil dikaitkan variabel-variabel sosial yang lain. Apabila hukum sebagai gejala sosial yang empiris sifatnya,dikaji sebagai variabel bebas/sebab (independen variabel) yang menimbulkan pengaruh dan akibat pada berbagai aspek kehidupan sosial,kajian ini merupakan kajian hukum yang sosiologis (sociolegal resect) namun, jika hukum dikaji sebagai variabel tergantug atau akibat (independen variabel) yang timbul sebagai hasil dari berbagai kekuatan dalam proses sosial, kajian itu merupakan kajian sosiologis hukum (sosiology of law).

Dapat ditarik kesimpulan Dari kedua jenis penelitian diatas peneliti, menggunakan metode penelitian hukum empiris, metode penelitian hukum empiris, yaitu untuk mengamati bagaimana fakta yang terjadi di lapangan atau dalam masyarakat, sehingga peneliti dapat mempermudah untuk mendapatkan datadata di lapangan sesuai dengan harapan dalam penelitian.

Adapun alasan peneliti menggunakan metode pendekatan sosiologis hukum adalah karena dalam mengungkapkan kejadian atau peristiwa sosial di lapangan tentu sumber informasi atau data yang diberikan oleh informan kepada peneliti melalui wawancara, observasi atau data resmi yang berupa dokumen yang ada relefansinya dengan data atau hasil penelitian yang ingin dicapai oelh peneliti. Dalam proses penelitian ini untuk mendapatkan data atau informasi yang diperoleh langsung dalam masyarakat setempat, dan tugas peneliti adalah mengkaji tentang apa yang ada dibalik yang tampak tentang Upaya kepolisian dalam penanggulangan tindak pidana kekerasan yang dilakukan oleh pelajar (Studi di wilayah hukum Polres Dompu).

\section{Subjek Penelitian}

Peneliti merupakan kunci utama dalam memperoleh data, peneliti sendiri atau dengan bantuan orang lain merupakan alat pengumpul data utama [10]. Selain itu juga dalam penelitian kualitatif, peneliti di anggap sebagai human instrument, berfungsi menetapkan fokus penelitian, memilih informan sebagai sumber data, menafsirkan data dan membuat kesimpulan atas temuannya [11]. Dengan ini, subjek utama dan pertama dalam penelitian kasus ini adalah pihak yang bersangkutan yaitu Kasat reskrim Dompu, bagian penyidik, anggota kepolisian, pelajar atau anak yang ada di wilayah hukum Polres Dompu.

\section{Metode Pengumpulan Data}

Data penelitian ini teknik pengumpulan data dilakukan dengan tiga cara yaitu:

a) Metode Observasi

Menurut Faisal dalam [12] mengklasifikasi-kan observasi menjadi observasi berpartisipasi (participant obsevation), observasi yang secara terang-terangan dan tersamar (overt observation dan covert observation), dan observasi yang tak berstruktur (unstruktur observation).

b) Metode Wawancara 
Menurut Esterberg [12] mengemukakan beberapa macam-macam wawancara, dari yaitu, wawancara terstruktur, wawancara Semi terstruktur dan wawancara tidak terstruktur. Oleh karena itu, dalam hal ini peneliti mengambil metode wawancara yang terstruktur dimana peneliti telah mengetahui dengan pasti tentang informasi apa yang akan diperoleh. Oleh karena itu dalam melakukan wawancara, pengumpul data telah menyiapkan instrumen penelitian berupa pertanyaan tertulis yang alternatif jawabanya pun telah disiapkan. Dengan wawancara terstruktur ini setiap responden diberi pertanyaan yang sama, dan pengumpulan data mencatatnya

c) Metode Dokumentasi

Metode dokumentasi, yaitumencari data mengenai hal-hal atau variabel yang berupa catatan, tanskrip, buku, surat kabar, majalah, prasasti, notulen rapat, lengger, agenda,dan sebagainya [12].

\section{HASIL DAN PEMBAHASAN}

1. Upaya Kepolisian Dalam Penanggulangan Tindak Pidana Kekerasan oleh Pelajar

Upaya-upaya yang telah dilakukan oleh Polres Dompu untuk menanggulangi tindak pidana kekerasan yang dilakukan oleh pelajar di Kabupaten Dompu berikut:

1) Penyuluhan

Melakukan penyuluhan-penyuluhan yang dilakukan di sekolah-sekolah, kantor Desa dan Kecamatan ditujukan kepada warga desa atau Kecamatan yang secara khusus adalah kepada anak pelajar dan remaja dan juga kepada Karang taruna yang beranggotakan para pemuda dan anak pelajar di desa atau kecamatan setempat maupun di Instansi pemerintahan untuk memberikan pemahaman tentang apa itu tindak pidana kekerasan dan sanksi hukum yang akan dijatuhkan apabila melakukan tindak pidana kekerasan.

Pemberian pemahaman ini bertujuan agar anak pelajar atau remaja tidak melakukan tindak pidana kekerasan dan tahu akan bahaya yang ditimbulkan apabila melakukan tindak pidana kekerasan, dengan dilakukan penyuluhan ini diharapkan masyarakat khususnya anak pealajar dan remaja dapat ikut serta berpartisipasi dalam membantu memberantas tindak pidana kekerasan dengan cara menghindari perbuatan melakukan kekerasan serta jika ditemukan atau mengalami suatu tindak pidana kekerasan oleh pelajar segera melaporkan kepada pihak kepolisian tentang adanya tindak pidana kekerasan yang dilakukan oleh pelajar.

2) Kerjasama

Melakukan kerja sama dengan berbagai komponen antara lain Lembaga Pembinaan Khusus Anak, Lembaga Penempatan Anak Sementara, Lembaga Penyelenggaraan
Kesejahteraan Sosial, Balai Pemasyarakatan, dan Instansi-instansi lain yang terkait.

3) Tindakan pencegahan

Upaya pencegahan yang dilakukan Kepolisian Resort Dompu seperti melakukan patroli, pengawasan oleh babinsa yang dibantu oleh masyarakat dalam hal melakukan ronda malam mencari anak-anak pelajar yang suka melakukan tindak pidana kekerasan seperti di jalan raya, ditempat keramaian atau acara-acara malam seperti orkestra ataupun di Lapangan terbuka tempat mereka janjian untuk berkelahi.

4) Upaya Represif

Kepolisian Resort Dompu dalam menanggulangi tindak Pidana kekerasan yang dilakukan oleh pelajar di Kabupaten Dompu, Upaya Represif merupakan upaya penindakan.

Peradilan restorative terarah pada pembangkitan rasa tanggungjawab anak pelaku dengan cara perbaikan kerugian dan penyembuhan luka masyarakat pun terpenuhi untuk berperan aktif "mendidik" anak untuk mempertanggungjawabkan perbuatannya baik terhadap korban, keluarganya, masyarakat pada umumnya. Atas dasar semua itu, maka perlu adanya amandeman UU No.3 tahun 1997 tentang Pengadilan Anak yang mengarah pada pengakomodasian ketentuan-ketentuan yang memungkinkan dijiwainya model peradilan anak restoratif masa datang di Indonesia[13]. Senada juga bahwa dalam Undang-Undang Nomor 11 Tahun 2012[14] telah sesuai dengan prinsip perlindungan hukum terhadap anak pelaku tindak pidana baik menurut instrumen hukum nasional maupun internasional, hal ini dapat diketahui dengan dianutnya beberapa asas yang harus dikedepankan dalam pelaksanaan sistem peradilan pidana anak. Kebijakan penanggulangan kejahatan terhadap anak pelaku tindak pidana di dalam Undang-Undang Nomor 11 Tahun 2012 dilakukan dengan sarana penal dan non penal. Sarana penal dilakukan dengan penerapan sistem peradilan pidana yang dimulai dengan proses penyidikan, penuntutan, persidangan, pembinaan lembaga. Sarana non penal dilakukan dengan penerapan upaya Diversi dan Restorative Justice, namun dalam penerapannya sarana non penal juga dilakukan dalam sarana penal.

\section{Faktor Yang Menyebabkan Anak Melakukan Tindak Pidana Kekerasan}

Adapun beberapa faktor yang menyebabkan Pelajar ini melakukan Tindak Pidana kekerasan antara lain:

a) Lingkungan, di mana lingkungan yang saya tinggali itu sangat rawan melakukan tindak pidana kekersan,

b) Keluarga, kurang nya pengawasan darikeluarga saya (wawancara dengan Anas, Andika, dan Wendy 22 Mei 2017)

Anak lainnya pun memberikan alasan dia melakukan pencabulan karena rasa ingin tahu saya 
terhadap cewek itu, serta kurangnya pengawasan dari orang tua (wawancara dengan Anahar Rula 22 Mei 2017)

Dari wawancara di atas peneliti menyimpulkan faktor-faktor yang menyebabkan anak melakukan tindak pidana kekerasan:

a) Faktor Internal.

Remaja yang terlibat perkelahian biasanya kurang mampu melakukan adaptasi pada situasi lingkungan yang kompleks. Kompleks di sini berarti adanya keanekaragaman pandangan, budaya, tingkat ekonomi, dan semua rangsang dari lingkungan yang makin lama makin beragam dan banyak. Situasi ini biasanya menimbulkan tekanan pada setiap orang. Tapi pada remaja yang terlibat perkelahian, mereka kurang mampu untuk mengatasi, apalagi memanfaatkan situasi itu untuk pengembangan dirinya. Mereka biasanya mudah putus asa, cepat melarikan diri dari masalah, menyalahkan orang/pihak lain pada setiap masalahnya, dan memilih menggunakan cara tersingkat untuk memecahkan masalah. Pada remaja yang sering berkelahi, ditemukan bahwa mereka mengalami konflik batin, mudah frustrasi, memiliki emosi yang labil, tidak peka terhadap perasaan orang lain, dan memiliki perasaan rendah diri yang kuat. Mereka biasanya sangat membutuhkan pengakuan.

\section{b) Faktor Keluarga}

Rumah tangga yang dipenuhi kekerasan (entah antar orang tua atau pada anaknya) jelas berdampak pada anak. Anak, ketika meningkat remaja, belajar bahwa kekerasan adalah bagian dari dirinya, sehingga adalah hal yang wajar kalau ia melakukan kekerasan pula. Sebaliknya, orang tua yang terlalu melindungi anaknya, ketika remaja akan tumbuh sebagai individu yang tidak mandiri dan tidak berani mengembangkan identitasnya yang unik. Begitu bergabung dengan teman-temannya, ia akan menyerahkan dirnya secara total terhadap kelompoknya sebagai bagian dari identitas yang dibangunnya.

\section{c) Faktor Sekolah}

Sekolah pertama-tama bukan dipandang sebagai lembaga yang harus mendidik siswanya menjadi sesuatu. Tetapi sekolah terlebih dahulu harus dinilai dari kualitas pengajarannya. Karena itu, lingkungan sekolah yang tidak merangsang siswanya untuk belajar (misalnya suasana kelas yang monoton, peraturan yang tidak relevan dengan pengajaran, tidak adanya fasilitas praktikum, dsb.) akan menyebabkan siswa lebih senang melakukan kegiatan di luar sekolah bersama teman-temannya. Baru setelah itu masalah pendidikan, di mana guru jelas memainkan peranan paling penting. Sayangnya guru lebih berperan sebagai penghukum dan pelaksana aturan, serta sebagai tokoh otoriter yang sebenarnya juga menggunakan cara kekerasan (walau dalam bentuk berbeda) dalam "mendidik" siswanya.

d) Faktor Lingkungan

Lingkungan di antara rumah dan sekolah yang sehari-hari remaja alami, juga membawa dampak terhadap munculnya perkelahian. Misalnya lingkungan rumah yang sempit dan kumuh, dan anggota lingkungan yang berperilaku buruk (misalnya narkoba). Begitu pula sarana transportasi umum yang sering menomor-sekiankan pelajar. Juga lingkungan kota (bisa negara) yang penuh kekerasan. Semuanya itu dapat merangsang remaja untuk belajar sesuatu dari lingkungannya, dan kemudian reaksi emosional yang berkembang mendukung untuk munculnya perilaku berkelahi.

\section{Kendala Yang Dihadapi Kepolisian dalam Menangani Masalah Tindak Pidana Kekerasan oleh Pelajar}

Dalam melakukan upaya pencegahan dan penanggulangan tindak pidana kekerasan yang dilakukan oleh palajar Kepolisian Resort Dompu mengalami beberapa kendala yang sibebakan karena beberapa faktor antara lain:

1) Pelaku Bungkam

Dengan status tersangka yang seorang pelajar dan jelas masih di bawah umur para penyidik tidak bisa melakukan penyidikan yang sama halnya seperti penyidikan terhadap orang dewasa, karena tersangka belum siap untuk berurusan dengan masalah yang masuk dalam ranah hukum, sehingga dia akan selalu menutup diri dan cenderung bungkam pada saat pelaksanaan penyidikan.

2) Balai Pemasyarakatan (BAPAS)

Pada tingkat pemeriksaan dan penelitian terhadap tersangka anak oleh BAPAS sering mengalami keterlambatan, jadi hasilnya pun sering terlambat diterima oleh Penyidik Polresta Padang. Di dalam Undang-undang sendiri baik oleh KUHAP maupun UT Pengadilan Anak memang tidak diatur kapan batas waktu lamanya pemeriksaan dan penelitian yang dilakukan oleh pihak BAPAS terhadap tersangka anak, pihak BAPAS tidak memilikiacuan pasti tentang berapa lamanya. melakukan penelitian terhadap tersangka anak. Jadi dengan kata lain pihak BAPAS mengacu hanya pada lamanya masa penahanan tersangka anak oleh pihak penyidik kepolisian.

3) OrangTua.

Penyidik/penyidik pembantu terkadang mendapatkan kendala dalam pelaksanaan penyidikan karena orang tua tersangka yang enggan untuk memberi keterangan dan mendampingi anak dalam proses penyidikan. Orang tua dari tersangka tindak pidana anak biasanya takut dan malu untuk mendampingi anaknya dalam pelaksanaan penyidikan sehingga penyidik tidak bisa melakukan 
penyidikan terhadap tersangka karena dalam penyidikan terhadap tersangka anak harus didampingi oleh orang tuanya (Wawancara, Daniel AKP Simonguncong 25 mei 2017)

\section{TEMUAN DAN DISKUSI}

Upaya kepolisian dalam penanggulangan tindak pidana kekerasan yang dilakukan oleh pelajar di Dompu antara lain:

a) Melakukan penyuluhan-penyuluhan yang dilakukan di sekolah-sekolah, kantor Desa dan Kecamatan ditujukan kepada warga desa atau Kecamatan yang secara khusus adalah kepada anak pelajar dan remaja dan juga kepada Karang taruna yang beranggotakan para pemuda dan anak pelajar di desa atau kecamatan setempat maupun di Instansi pemerintahan untuk memberikan pemahaman tentang apa itu tindak pidana kekerasan dan sanksi hukum yang akan dijatuhkan apabila melakukan tindak pidana kekerasan.pemberian pemahaman ini bertujuan agar anak pelajar atau remaja tidak melakukan tindak pidana kekerasan dan tahu akan bahaya yang ditimbulkan apabila melakukan tindak pidana kekerasan.dengan dilakukan penyuluhan ini diharapkan masyarakat khususnya anak pealajar dan remaja dapat ikut serta berpartisipasi dalam membantu memberantas tindak pidana kekerasan dengan cara menghindari perbuatan melakukan kekerasan serta jika ditemukan atau mengalami suatu tindak pidana kekerasan oleh pelajar segera melaporkan kepada pihak kepolisian tentang adanya tindak pidana kekerasan yang dilakukan oleh pelajar.

b) Melakukan kerja sama dengan berbagai komponen antara lain Lembaga Pembinaan Khusus Anak, Lembaga Penempatan Anak Sementara, Lembaga Penyelenggaraan Kesejahteraan Sosial, Balai Pemasyarakatan, dan Instansi-instansi lain yang terkait.

c) Upaya pencegahan yang dilakukan Kepolisian Resort Dompu seperti melakukan patroli, pengawasan oleh babinsa yang dibantu oleh masyarakat dalam hal melakukan ronda malam mencari anak-anak pelajar yang suka melakukan tindak pidana kekerasan seperti di jalan raya, ditempat keramaian atau acara-acara malam seperti orkestra ataupun di Lapangan terbuka tempat mereka janjian untuk berkelahi.

d) Kepolisian Resort Dompu dalam menanggulangi tindak Pidana kekerasan yang dilakukan oleh pelajar di Kabupaten Dompu, Upaya Represif merupakan upaya penindakan.

Dapat disimpulkan bahwa Upaya Kepolisian dalam Penaggulangan tindak pidana kekerasan yang dilakukan oleh pelajar, sangat banyak penanggulangan yang dilakukan oleh kepolisian seperti melakukan penyeluhan-penyeluhan disetiap sekolah mengadakan patroli, ronda malam serta kepolisian melakukan kerja sama dengan pihak atau lembaga yang besangkutan sehinnga penanggulangan yang dilakukan oleh kepolisian sangat baik dalam menanggulangi tindak pidana yang dilakukan oleh pelajar di Dompu.

Kehadiran Hukum Pidana di tengah masyarakat dimaksudkan untuk memberikan rasa aman kepada individu maupun kelompok masyarakat dalam melaksanakan aktifitas kesehariannya. Hukum Pidana memiliki beberapa asas yang menjadi acuan dalam teori penerapan hukum pidana[15]. Pemulihan atau perlindungan anak-anak yang menjadi korban perdagangan manusia (child trafficking) bahkan setelah penyelesaian proses pidana dengan pandangan untuk memulihkan masa depan anak melalui rekonsialisasi hukum[16].

Kendala yang Dihadapi Kepolisian Dalam Menangani Tindak Pidana Kekerasan oleh Pelajar diuraikan berikut ini.

1) Pelaku Bungkam

Dengan status tersangka yang seorang pelajar dan jelas masih di bawah umur para penyidik tidak bisa melakukan penyidikan yang sama halnya seperti penyidikan terhadap orang dewasa, karena tersangka belum siap untuk berurusan dengan masalah yang masuk dalam ranah hukum, sehingga dia akan selalu menutup diri dan cenderung bungkam pada saat pelaksanaan penyidikan.

2) Balai Pemasyarakatan (BAPAS)

Pada tingkat pemeriksaan dan penelitian terhadap tersangka anak oleh BAPAS sering mengalami keterlambatan, jadi hasilnya pun sering terlambat diterima oleh Penyidik Polresta Padang. Di dalam Undang-undang sendiri baik oleh KUHAP maupun UT Pengadilan Anak memang tidak diatur kapan batas waktu lamanya pemeriksaan dan penelitian yang dilakukan oleh pihak BAPAS terhadap tersangka anak, pihak BAPAS tidak memilikiacuan pasti tentang berapa lamanya. melakukan penelitian terhadap tersangka anak. Jadi dengan kata lain pihak BAPAS mengacu hanya pada lamanya masa penahanan tersangka anak oleh pihak penyidik kepolisian.

3) Orang Tua.

Penyidik/penyidik pembantu terkadang mendapatkan kendala dalam pelaksanaan penyidikan karena orang tua tersangka yang enggan untuk memberi keterangan dan mendampingi anak dalam proses penyidikan. Orang tua dari tersangka tindak pidana anak biasanya takut dan malu untuk mendampingi anaknya dalam pelaksanaan penyidikan sehingga penyidik tidak bisa melakukan penyidikan 
terhadap tersangka karena dalam penyidikan terhadap tersangka anak harus didampingi oleh orang tuanya.

Dapat disimpulkan kendala yang diahadapi oleh Kepolisian dalam menangani tindak pidana kekerasan yang dilakukan oleh pelajar di dompu, yaitu dimana anak yang melakukan tindak pidana tidak mau memberikan penjelasan kenapa dia melakukan tindak pidana, serta tidak adanya Balai Pemasyarakatan di Dompu sehinnga memperlambat proses penyelidikan, serta orang tua yang tidak mau mendampingi anaknya saat proses penyelidikan dilakukan karena merasa malu maupun marah, kecewa kepada anaknya.

\section{E. SIMPULAN DAN SARAN}

Upaya-upaya kepolisian Resort Dompu dalam menanggulangi tindak pidana kekerasan yang dilakukan oleh pelajar di Kabupaten Dompu adalah 1) Upaya preemtifPembinaan pelajar melalui jalur pembina upacara, ceramah, diskusi dan penyuluhan tentang tindak pidana kekerasan. 2) Upaya preventif melakukan upaya pencegahan dengan cara koordinasi lintas sektoral untuk mengawasi pelajar yang terlihat di luar sekolah pada saat jam pelajaran, di lingkungan masyarakat serta melakukan pemeriksaan senjata tajam. 3) Upaya represif penindakan secara hukum (diproses), dan diberikan tindakan-tindakan tertentu. Tindakan represif tidak selalu dilakukan penahanan atau melaksanakan proses penyidikan. Tetapi juga dapat dengan memberikan tindakan seperti membuat surat pernyataan atau dengan tindakan hukuman seperti membotaki rambut pelajar yang melakukan tindak pidana kekersan.

Kendala yang dihadapi kepolisian Resort Dompu dalam menangani masalah tindak pidana kekerasan yang dilakukan oleh pelajar di Kabupaten Dompu adalah karena pelaku bungkam, kelebihan peanmpungan di Balai Pemasyarakatan (BAPAS), kurang pengawasan orang tua.

Adapun hal-hal yang dapat disarankan adalah sbagai berikut:

a) Pemerintah harus berperan aktif khusunya Pemerintah Daerah Kabupaten Dompu untuk memberikan dukungan baik berupa moral dan materil dalam upaya menanggulangi tindak pidana kekerasan yang dilakukan oleh pelajar di Kabupaten Dompu.

b) Penegak Hukum Khususnya Pihak Kepolisian Resort Dompu harus dapat mengupayakan kerjasama yang serius dengan Instansi-instansi lain yang terkait dalam Upaya menanggulangi tindak pidana kekerasan yang dilakukan oleh pelajar di Kabupaten Dompu.

c) Orang Tua dalam hal menghadapi anak yang melakukan tindak pidana kekerasan harus dapat menjadi pendamping yang aktif serta harus terbuka kepada aparat penegak hukum untuk memberikan keterangan yang jelas dan rinci tentang anak yang melakukan tindak pidana kekerasan.

d) Masyarakat dalam hal ini pihak Desa maupun tokoh-tokoh masyarakat dapat memberikan sumbangan nasehat kepada anak yang melakukan tindak pidana kekerasan yang dilakukan oleh pelajar.

\section{UCAPAN TERIMA KASIH}

Penulis mengucapkan terima kasih kepada LPPM Universitas Muhammadiyah Mataram yang senantiasa memberikan bimbingan, nasehat, dan motivasi kepada penulis sehingga penelitian ini dapat diselesaikan tepat waktu sesuai yang direncanakan.

\section{DAFTAR RUJUKAN}

[1] Moeljatno, Azas-asas Hukum Pidana. Seksi Hukum Pidana Fakultas Hakum Universitas Gadjah Mada, 1969.

[2] H. O. Sinaga, "Penanggulangan Kejahatan Internasional Cyber Crime di Indonesia," Abstrak, 2010.

[3] A. M. Nurwijayanti, "Eksploitasi anak: Perlindungan hukum anak jalanan dalam perspektif hukum pidana di Daerah Yogyakarta." Universitas Muhammadiyah Surakarta, 2012.

[4] E. Sitindaon, A. Khair, and M. Marlina, "Sistem Pemidanaan terhadap Anak sebagai Pelaku Tindak Pidana Sebelum dan Sesudah Pengaturan Restoratif Justice di Indonesia," J. Mahupiki, vol. 1, no. 1, 2012.

[5] R. Indonesia, "Undang-undang RI 2 Tahun 2002 tentang Kepolisian Negara Republik Indonesia," Tersedia http//www. dpr. go. id. Html [12 Sept. 2013], 2002.

[6] R. Indonesia and D. K. dan Informatika, Undangundang Republik Indonesia nomor 14 tahun 2008 tentang keterbukaan informasi publik. Departemen Komunikasi dan Informatika, 2008.

[7] P. A. F. Lamintang, "Delik-delik Khusus Tindak Pidana Melanggar Norma-norma Kesusilaan dan Norma Kepatutan.” Mandar Maju, Bandung, 2002.

[8] Sadjijono, "Memahami Hukum Kepolisian." LaksBang Press Sindo: Yogyakarta, 2010.

[9] R. Indonesia, "Undang-undang Nomor 2 Tahun 2002 tentang Kepolisian Negara Republik Indonesia," Kepol. Negara Republik Indones., 2AD.

[10] L. J. Moleong, "Metodologi Penelitian Kualitatif,(Bandung: Remaja Rosdakarya, 2010), cet," Ke-13, $h$, vol. 111 .

[11] Sugiyono, Metode Penelitian Pendidikan $R \& D$. Bandung: Alfabeta, 2017.

[12] Sugiyono, Metode Penelitian Pendidikan:(Pendekatan Kuantitatif, Kualitatif dan $R \& D$ ). Alfabeta, 2014.

[13] P. Hadisuprapto, "Peradilan Restoratif: Model Peradilan Anak Indonesia Masa Datang," 2006.

[14] M. Novira and M. Marlina, "Kebijakan penanggulangan kejahatan terhadap anak pelaku tindak pidana dari perspektif undang-undang Republik Indonesia Nomor 11 Tahun 2012 
tentang sistem peradilan pidana anak," $J$. Mahupiki, vol. 1, no. 1, 2013.

[15] A. Ilyas, Asas-asas Hukum Pidana, memahami tindak pidana dan pertanggungjawaban pidana sebagai syarat pemidanaan. Rangkang Education, 2012.

[16] T. W. Widiastuti, "Upaya Pencegahan Tindak Pidana Perdagangan Orang (Trafficking)," $J$. Wacana Huk., vol. 9, no. 1, 2012. 